\title{
NEW SPECIES OF $A A$ AND NEW COMBINATIONS IN MYROSMODES (ORCHIDACEAE: CRANICHIDINAE) FROM BOLIVIA AND PERU
}

\author{
Delsy Trujillo ${ }^{1,3}$ \& Carlos A. Vargas ${ }^{2}$ \\ ${ }^{1}$ Museo de Historia Natural, Universidad Ricardo Palma, Av. Benavides 5440, Lima 33, Perú \\ ${ }^{2}$ AECOM, Montréal, Canada \\ ${ }^{3}$ Corresponding author: delsytrujillo@gmail.com
}

\begin{abstract}
A new species of $A a$ from northern Peru is described: Aa aurantiaca, which has highly atypical orange flowers for the genus. Furthermore, two new combinations of Myrosmodes are proposed: $M$. inaequalis and M. gymnandra, with illustrations and diagnostic features of the new species.

Resumen. Se describe una nueva especie de Aa del norte del Perú: Aa aurantiaca; la cual tiene las flores de color naranja, siendo éste un color inusual para el género. Se proponen además dos nuevas combinaciones de Myrosmodes: M. inaequalis y M. gymnandra; se presentan ilustraciones y se discuten rasgos diagnósticos de las nuevas especies.
\end{abstract}

Key words. : Orchidaceae, Cranichideae, Peru, Bolivia, Aa, Myrosmodes

The genera $A a$ Rchb.f. and Myrosmodes Rchb.f. consist of terrestrial orchids possessing tiny, white to greenish-white, non-resupinate flowers. Although there are some records of Aa paleacea (Kunth) Rchb.f. in the mountains of Costa Rica (Dressler 1993), the species of $A a$ and Myrosmodes are mostly restricted to the South American Andean mountain range at high elevations.

The taxonomic status of the representatives of these genera has remained unclear for many years. The genera $A a$ and Myrosmodes were first described by Reichenbach filius in 1854 . He distinguished $A a$ from Altensteinia Kunth and transferred Altensteinia paleacea (Kunth) Kunth to Aa [Aa paleacea (Kunth) Rchb.f.]. However, in a subsequent work Reichenbach (1878) reassessed his criteria and placed both $A a$ and Myrosmodes as synonyms of Altensteinia, and described nine new species, among them Altensteinia gymnandra Rchb.f. and Altensteinia inaequalis Rchb.f.. Later, Schlechter (1912, 1920a, 1920b) distinguished Aa from Altensteinia again but considered Myrosmodes as a synonym of $A a$ and combined it with that genus (e.g., Aa gymnandra (Rchb.f.) Schltr., Aa inaequalis (Rchb.f.) Schltr.). Subsequent taxonomists, for instance Schweinfurth (1958), recognized only Altensteinia as a valid genus and considered the other two genera as synonyms.
Garay (1978), as part of his work in Flora of Ecuador, revalidated the genera $A a$ and Myrosmodes and transferred some species of Aa and Altensteinia to Myrosmodes. Since then, the three genera have been widely accepted as distinct taxa. Further revision of Myrosmodes in Peru and Colombia led to the transfer of more species to this genus (Vargas 1995, Ortiz 1995 , respectively). Up to the point of this publication, Myrosmodes comprised about 10 species.

Morphologically, Altensteinia is distinguished from A $a$ and Myrosmodes by having a terminal inflorescence, pubescent column, lobulate clinandrium, small stigma and anthesis occurring after the full development of leaves (Garay 1978). Conversely, Aa and Myrosmodes possess a lateral inflorescence and glabrous column, and anthesis occurs before the full development of leaves. $A a$ has an elongate peduncle enveloped by tubular hyaline-diaphanous sheaths, with dorsal sepal and petals free from the column, lip calceolate with involute and lacerate margins, and in many species, a pilose ovary. Myrosmodes has at least 6 morphological and ecological characters that distinguish this genus from Aa and Altensteinia and the rest of Prescottiinae: (1) a short peduncle with infundibuliform, scarious sheaths, (2) a cucullate lip that is tubular or flared, with fimbriolate margins with moniliforms hairs (Garay 1978, Vargas 1997), (3) an accrescent peduncle (after 

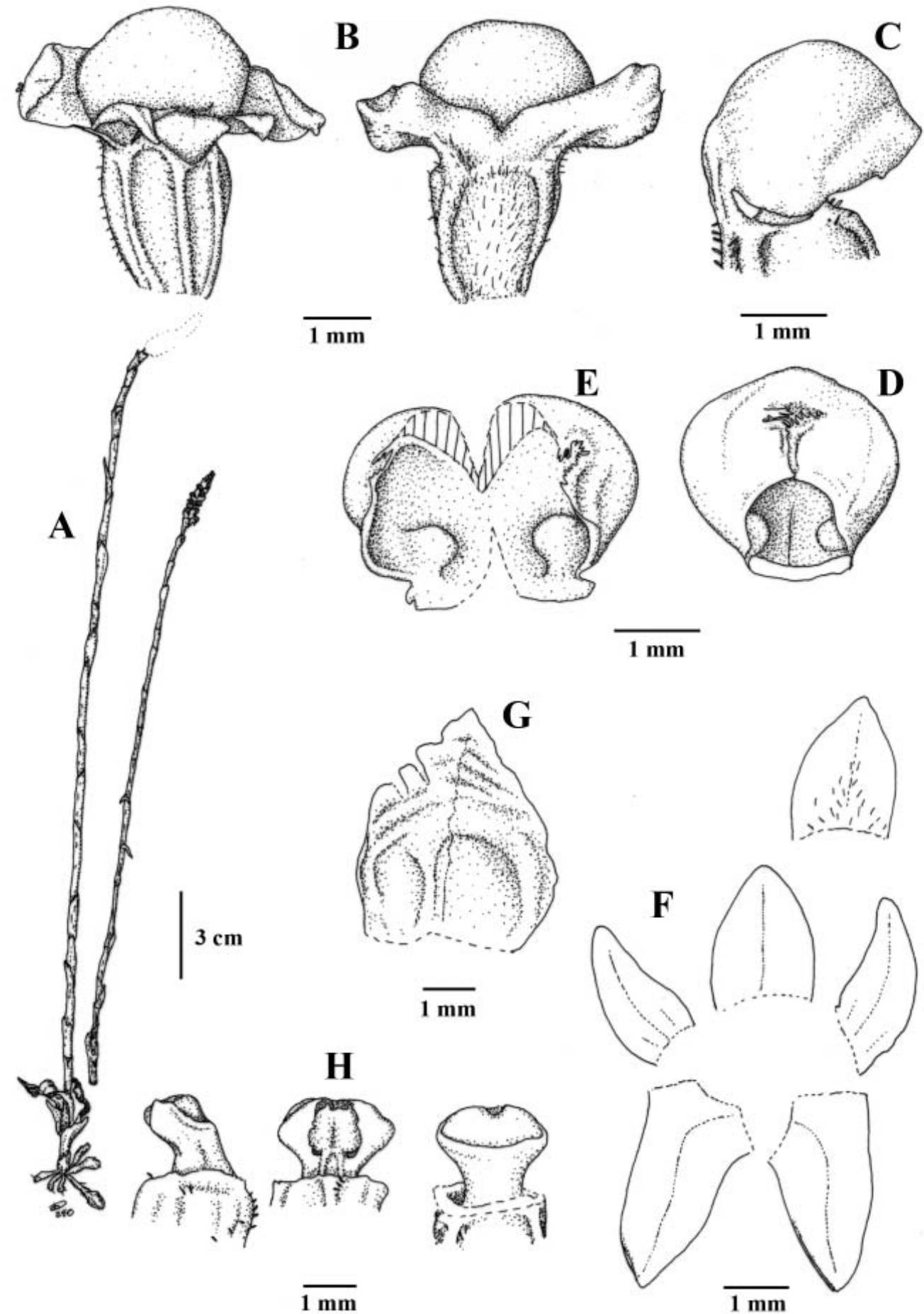
anthesis, the inflorescence peduncle elongates twice or more its original size, evident even in herbarium specimens), (4) basipetal floral development (with flowers growing from the inflorescence apex to its base), (5) andromonoecious inflorescence (with male flowers distinctly smaller (up to $300 \%$ ) than hermaphrodite flower (Berry \& Calvo 1991, Vargas 1997, and Trujillo pers. obs.), and (6) growing between 3300 to almost 5000 m.a.s.1 and mostly in wet puna/paramo highandean bogs from Venezuela to Argentina/Chile (world's record by Myrosmodes pumilio (Schltr.) C. Vargas, observed in Peruvian Andes and in bogs from Chile, Novoa, Vargas \& Cisternas, in prep.).

Although a recent DNA study indicates that Myrosmodes may be embedded within $\mathrm{Aa}$ and that the recognition of the genus Myrosmodes is tenuous (Álvarez-Molina \& Cameron 2009), the morphological and ecological evidence still supports its separation from $A a$.

Still, we are a long way from knowing all the species that constitutes the genera $\mathrm{Aa}$ and Myrosmodes. A careful examination of the floral features is necessary for the proper identification of the specimens, and this is only possible by dissecting the flowers under a stereomicroscope. For example, in most of the original descriptions and illustrations of Myrosmodes (as Aa or Altensteinia) the authors did not indicate or show the features of the column, mainly the anther (Reichenbach 1854, 1878, Schlechter 1912, 1920a, 1920b, Mansfeld 1929). The knowledge of these features in the other Myrosmodes species is required in order to have a clearer delimitation of the species that compose this genus.

Based on revisions of the type material from the Reichenbach Herbarium (W) as part of the identification of a new species of $A a$ from northern Peru, it has become evident that the following new combinations in Myrosmodes are necessary. They were also mentioned by Vargas in his work in Cranichideae and Prescottiinae (unpublished thesis 1997).

Aa aurantiaca D. Trujillo, sp. nov.

TYPE: Peru. Dept. La Libertad: Prov. Santiago de Chuco, Quirovilca, Yanivilca, 3509 m, 22 May 2005, D. Trujillo 212 (holotype, HURP; isotypes, HAO, SEL, M) (FIG. 1, 2).

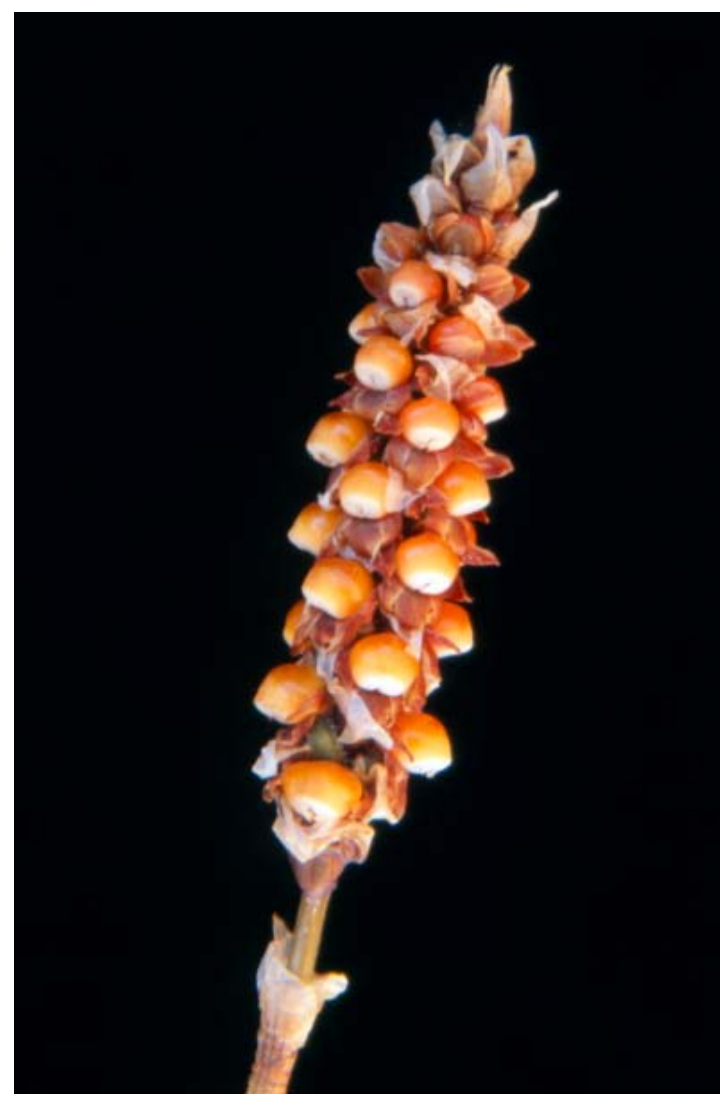

Figure 2. Inflorescence of Aa aurantiaca. Photograph by D. Trujillo.

Differt ab simili Aa rosea Ames flore aurantiaco, sepalis dorsaliter pilosis, petalis trinervatis ovatolanceolatis et foramine labelli angustiore.

Plant small, terrestrial. Roots fleshy, fasciculate, pubescent. Leaves withered at flowering time. Inflorescence slender, erect, up $30 \mathrm{~cm}$ long, enclosed by up to 23 diaphanous sheaths, terminated in a densely many flowered cylindrical spike $2.2-5.0 \mathrm{~cm}$ long, rachis of the spike sparsely pilose. Floral bracts ovate, acute to obtuse, margins slightly erose, reflexed, 4-5 $\times 4 \mathrm{~mm}$, somewhat surpassing the flowers. Flowers non-resupinate, orange to reddish orange. Dorsal sepal oblong to ovate, obtuse, dorsally hairy, 1-nerved, reflexed, $2.0 \times 1.3-1.5 \mathrm{~mm}$. Lateral sepals shortly connate at the base, obliquely oblong-lanceolate, obtuse, dorsally hairy, somewhat carinate, 1-nerved, $3.0 \times 1.5 \mathrm{~mm}$. Petals obliquely ovate lanceolate, obtuse, 3-nerved, reflexed, up to $2.3 \times 1.1 \mathrm{~mm}$. Lip 


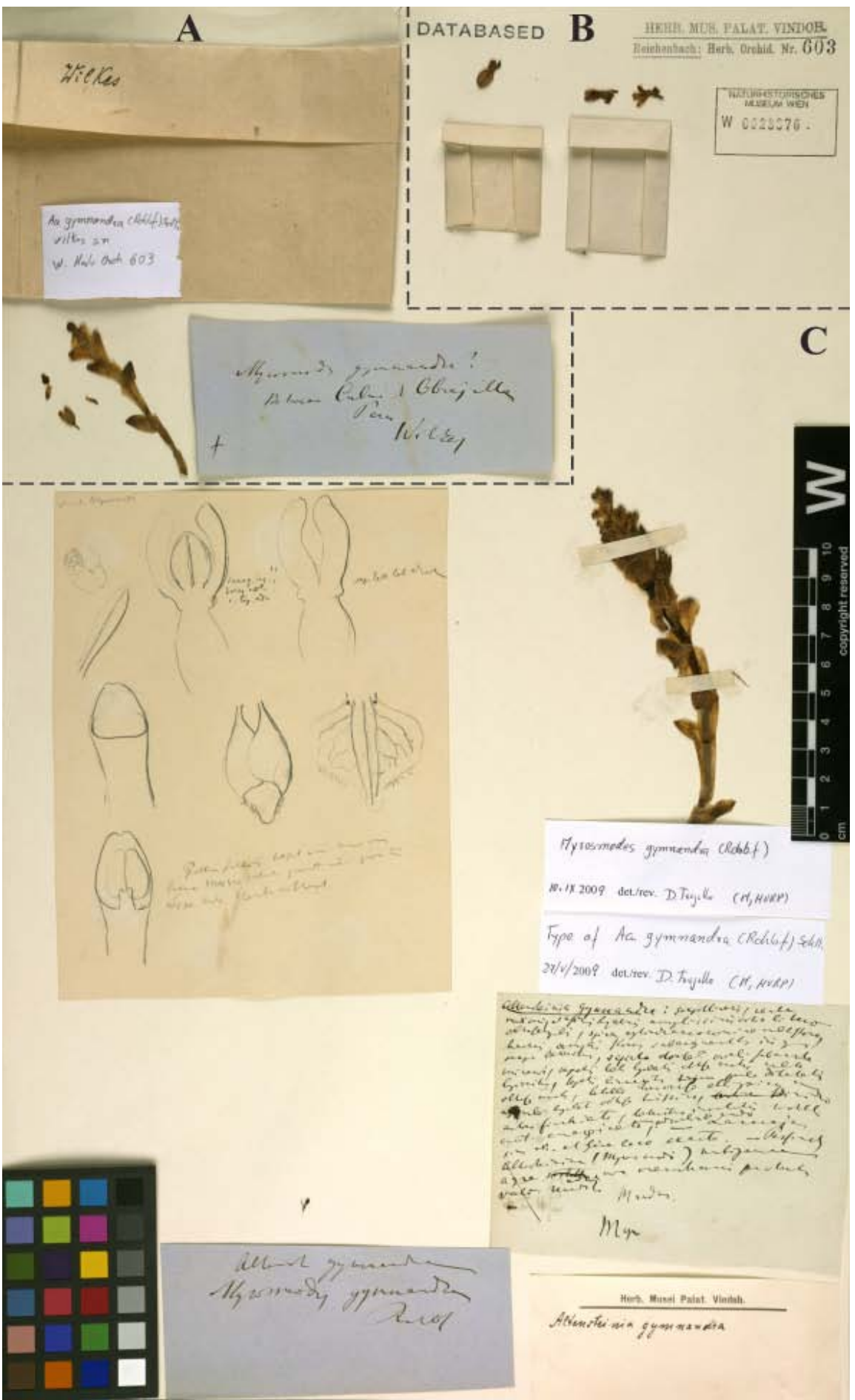

FiguRE 3. Single herbarium sheet at W-R bearing specimens of Myrosmodes gymnandra (Rchb.f.) C. Vargas composed of a mixed collection. A - Specimen Wilkes s.n. B - Specimens without collector information. C - Specimen Mandon s.n. (holotype). 
calceolate (semiglobose), transversely elliptic, fleshy (except the margins), obscurely 3-lobed, with a narrow opening, the involute margins lacerate, base with two spherical calli, $2.0 \times 2.5 \mathrm{~mm}$ (natural position). Column short, with an emarginate transverse rostellum, dilated above, $1.5 \mathrm{~mm}$ long, straight in young flowers and bent in old flowers. Anther erect, lateral margins lightly covered by the clinandrium. Stigma quadrate in young flowers and transversely elongate in old flowers. Ovary sessile, subcylindric, hairy, $2 \mathrm{~mm}$ long.

EтумоLogy: From Latin aurantiacus, referring to the orange color of the flowers.

Distribution: Known only from the Department of La Libertad, Peru, between 3500 and 4000 m elevation.

Phenology: Flowering plants have been recorded between May and August.

Habitat and ecology: Plants of this species grow on grassy hillsides. Some populations grow sympatrically with other $A a$ species with white flowers; whose sepals and petals have light-green tones when young turning into light-cream to cream-brown when older (but never orange). Besides flower color, this $A a$ species can be distinguished from Aa aurantiaca by its wide opening lip, glabrous sepals and ovary, and acuminate floral bracts which notoriously surpass the flower (50\% larger).

Aa aurantiaca is similar to Aa rosei Ames, but it can be distinguished by the orange flowers, dorsally hairy sepals, ovate-lanceolate, 3-nerved petals, and narrower opening of the lip.

Myrosmodes gymnandra (Rchb.f.) C. Vargas, comb. nov.

Basionym: Altensteinia gymnandra Rchb.f., Xenia Orch. 3: 18. 1878. TYPE: Bolivia. Prov. Larecaja, Mandon s.n. (holotype: W) (Fig. 3, 4).

Aa gymnandra (Rchb.f.) Schltr., Rep. Spec. Nov. Regni Veg.11: 150. 1912.

Myrosmodes gymnandra belongs to the subgenus Myrosmodes, i.e. it does not have a rostrate ovary (Vargas 1995). The inflorescence is $13 \mathrm{~cm}$ long. The dorsal sepal is oblong, obtuse, $4.4 \times 2.0 \mathrm{~mm}$. The lateral sepals are oblong, concave, obtuse, somewhat carinate, $6.0 \times 2.6$ $\mathrm{mm}$. The petals are linear, subacute, with upper margin erose, $4.5 \times 0.6 \mathrm{~mm}$. The lip is obovate, subquadrate, involute, trilobate, middle lobe subquadrate, margin apical with moniliform hairs, two calli at the base, $4.5 \mathrm{x}$ $3.6 \mathrm{~mm}$. The column is erect, and $3 \mathrm{~mm}$ long. The anther exceeds the apex of the stigma, with a free filament, 1.1 $\mathrm{mm}$ long. The rostellum is triangular and obtuse. The ovary is ellipsoid, $3.5 \mathrm{~mm}$ long. The floral bracts are subcircular to obovate, $11.0 \times 10.2 \mathrm{~mm}$.

In the protologue of the description of $A$. gymnandra, Reichenbach indicates that the specimen used to describe the species was Mandon s.n. Bolivia, Provincia Larecaja, without referring to a specific locality. However, in the Reichenbach Herbarium in Vienna (W), there was no specimen of $A$. gymnandra bearing the characteristic printed label of G. Mandon (as most of Mandon's herbarium specimens). There is a herbarium sheet that contains the flower illustration as well as notes from Reichenbach with the description of A. gymnandra and a mix of two specimens (Fig. 3). One specimen is mounted on the herbarium sheet, which could be Mandon's specimen (holotype) and the other is in an envelope (top left of the herbarium sheet), that corresponds to Wilkes s.n., collected in Peru between Culnai and Obrajillo. The illustration showed here is based on the flower from the smallest envelope (middle) of the herbarium sheet (Fig. 3B), but it is not possible to precisely identify the specimen to which it belongs.

In the original description of $A$. gymnandra, Reichenbach (1878) did not mention two important features: the anther exceeds the apex of the stigma and the anther's filament is free (Fig. 4D). In Reichenbach's illustrations the free filament is also evident but the anther appears smaller (Fig. 3C). The free filament has been described as a distinct feature for Myrosmodes filamentosum (Mansf.) Garay. Even though M. gymnandra has some floral features similar to M. filamentosum, they can be distinguished because the latter has larger flowers, a short ovary neck and a slightly trilobate lip (Garay 1978).

Myrosmodes inaequalis (Rchb.f.) C. Vargas, comb. nov.

Basionym: Altensteinia inaequalis Rchb.f., Xenia Orch. 3: 19. 1878. TYPE: Peru. Dept. Puno: Macusani in puna brava, June 1854, Lechler 1950 (holotype: W, isotype: W, G, AMES, K.). (Fig. 5) Aa inaequalis (Rchb.f.) Schltr., Rep. Spec. Nov. Regni Veg. 11: 150. 1912. 

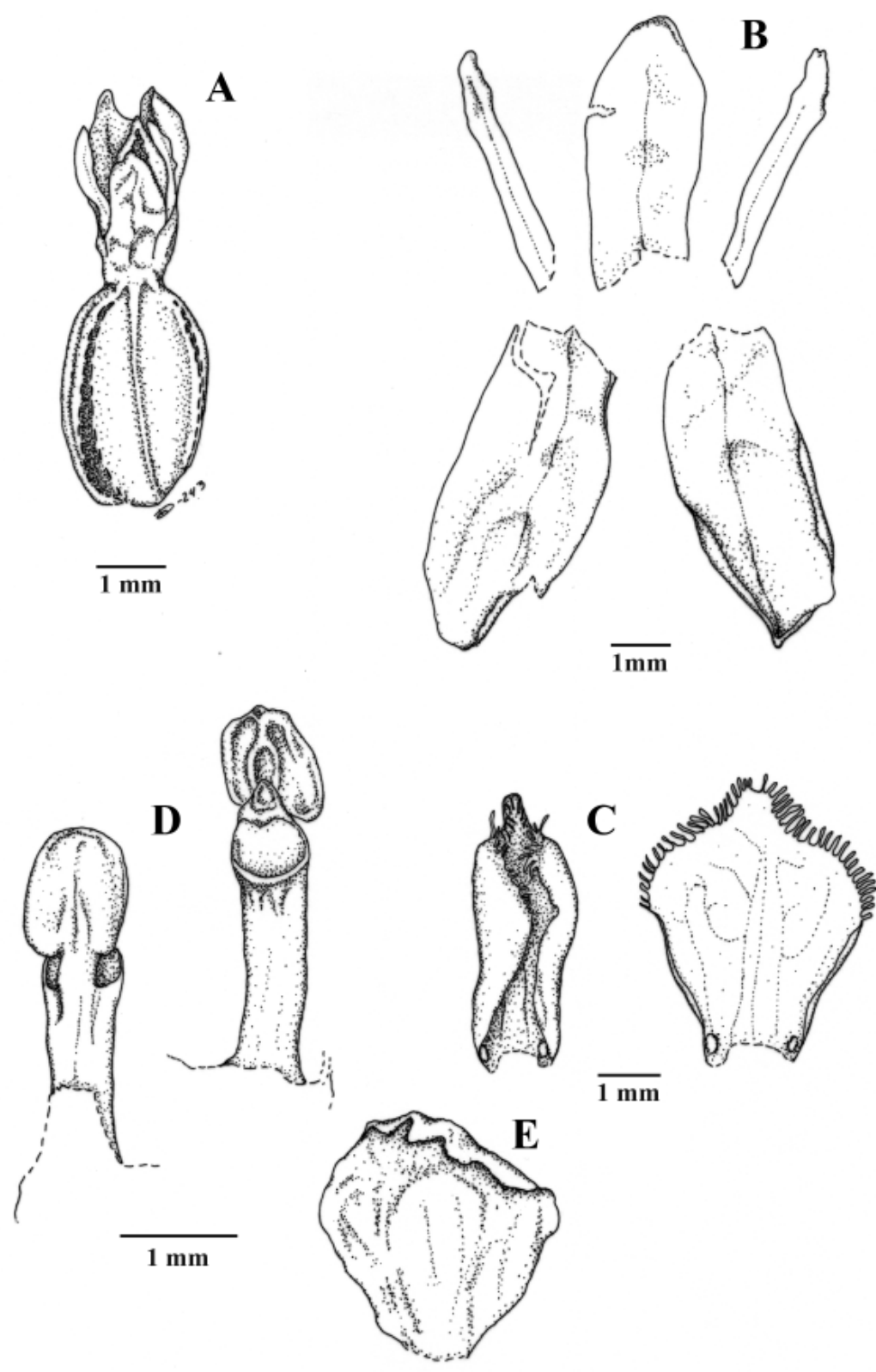

$5 \mathrm{~mm}$

Figure 4. Myrosmodes gymnandra (Rchb.f.) C. Vargas. A - Flower. B - Dissected perianth. C — Lip, left natural, right expanded out. D - Column, dorsal and ventral view. E - Floral bract. Drawing by D. Trujillo based on a specimen from Reichenbach Herbarium (W).

Myromodes inaequalis belongs to subgenus Myrosmodes (Vargas 1995). The inflorescence is up to $7 \mathrm{~cm}$ long. The dorsal sepal is oblong to oblongobovate, obtuse to rounded, concave, $2.3 \times 1.2 \mathrm{~mm}$. The lateral sepals are oblong, obtuse, concave, carinate, $2.6 \times 1.1 \mathrm{~mm}$. The petals are linear-ligulate, falcate, subacute, with upper margin erose, $2.0 \times 0.4$ $\mathrm{mm}$. The lip is cucullate, cuneate at base, obovate to elliptic when expanded, entire, margin of upper half with moniliform hairs, two calli at the base, $2.4 \times 2.1$ 


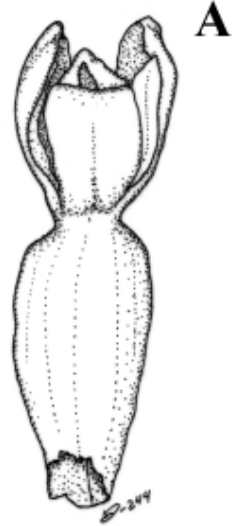

$\overline{1 \mathrm{~mm}}$

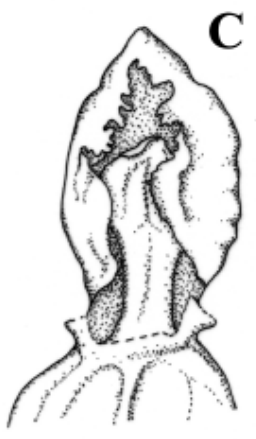

$1 \mathrm{~mm}$
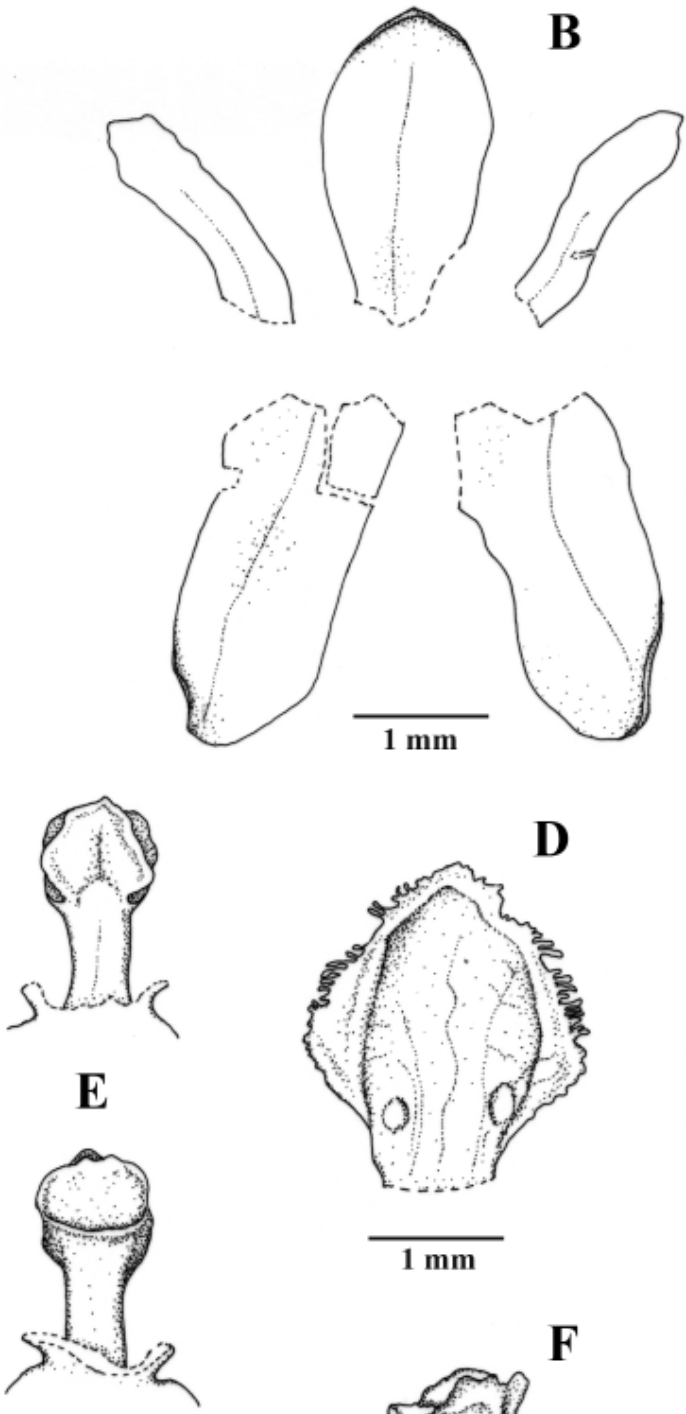

$1 \mathrm{~mm}$

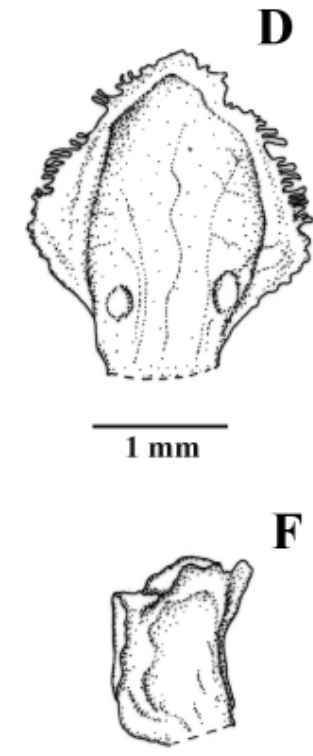

$3 \mathrm{~mm}$

Figure 5. Myrosmodes inaequalis (Rchb.f.) C. Vargas. A - Flower. B - Dissected perianth. C - Column and lip. D — Lip. E - Column, dorsal and ventral view. F - Floral bract. Drawing by D. Trujillo based on Lechler 1950 (W).

$\mathrm{mm}$. The column is erect, $1.6 \mathrm{~mm}$ long. The anther is subcircular and $0.7 \mathrm{~mm}$ long. The rostellum is truncate, emarginate, not triangular (as stated by Reichenbach). The ovary is elliptic, cylindrical, $3.5 \mathrm{~mm}$ long. The floral bracts are obovate to elliptic, $5 \mathrm{~mm}$ long.
Myrosmodes inaequalis resembles Myrosmodes paludosa (Rchb.f.) P. Ortiz.; however, they can be distinguished because the latter has a shorter anther, column dilated above, longer spike with more flowers and thicker peduncle which is twice as long as the 
spike (while in $M$. inaequalis the peduncle is up to three times longer than the spike).

ACKNOWLEDGEMENTS. We thank to the curators of the W for having allowed us access to the type material in the Reichenbach Herbarium, including rehydration of flowers of some of the specimens mentioned here; to the Ministerio de Agricultura of Peru and its Dirección General Forestal y de Fauna Silvestre (DGFFS) for issuing the collection permits under which orchid specimens have been collected ( $\mathrm{N}^{\circ}$ 030-2005-INRENA-IFFS-DCB); to the EES Grants for their sponsorship in visiting the W; to Dr. Günter Gerlach for his comments on the paper and to Dr. Philomena Bodensteiner for her help with the Latin diagnosis.

\section{Literature Cited}

Álvarez-Molina, A. \& K.M. Cameron. 2009. Molecular phylogenetics of Prescottiinae s.l. and their close allies (Orchidaceae, Cranichideae) inferred from plastid and nuclear ribosomal DNA sequences. Amer. J. Bot. 96: 1020-1040.

Ames, O. 1922. Aa rosei Ames. Proc. Biol. Soc. Wash. 35: 81.

Berry, P.E. \& R.N. Calvo. 1991. Pollinator limitation and position dependent fruit set in the high Andean orchid Myrosmodes cochleare (Orchidaceae). Pl. Syst. Evol. 174: 93-101.

Dressler, R.L. 1993. Field guide to the orchids of Costa
Rica and Panama. Cornell University Press, Ithaca, New York.

Garay, L.A. 1978. Orchidaceae. Cypripedioideae Orchidoideae Neottioideae. In: G. Harling \& B. Sparre (eds.), Flora of Ecuador, 225(1). University of Goteborg, Stockholm, Sweden.

Mansfeld, R. (ed.). 1929. Figuren-Atlas zu den Orchideenfloren der südamerikanischen Kordillerenstaaten. Repert. Sp. Nov. Regni Veg. Beih 57.

Ortiz, P. 1995. Orquídeas de Colombia. Corporación Capitalina de Orquideologia, Bogota. 2da. Ed.

Reichenbach, H.G. 1854. Altensteinia, Aa and Myrosmodes. Xenia Orchid. 1: 17-19.

Reichenbach, H.G. 1878. Orchideae Mandonianae. Xenia Orchid. 3: 17-19.

Schlechter, R. 1912. Die Orchideen Gattungen Altensteinia HBK, Aa Rchb.f. und Myrosmodes Rchb.f.. Repert Spec. Nov. Regni Veg. 11: 147-150.

Schlechter, R. 1920a. Orchidaceae novae et criticae. Repert. Sp. Nov. Regni Veg. 16: 353-358.

Schlechter, R. 1920b. Orchidaceae novae et criticae. Repert. Sp. Nov. Regni Veg. 16: 437-450.

Schweinfurth, C. 1958. Orchids of Peru. Fieldiana Bot.. 30(1): 1-260.

Vargas, C. 1995. New combinations in Myrosmodes Rchb.f. (Orchidaceae) Lindleyana 10: 5-6.

Vargas, C. 1997. Phylogenetic analysis of Cranichideae and Prescottiinae (Orchidaceae) with some taxonomic changes in Prescottiinae. M.S. thesis, University of Missouri-St. Luis, St. Louis Missouri, USA. 